\title{
NEOPROTEROZOIC GRANITOID SUITES IN SOUTHEASTERN BRAZIL
}

\section{ESSAÏD BILAL ${ }^{1}$, ADOLF HEINRICH HORN ${ }^{2}$, HERMINIO ARIAS NALINI JR. ${ }^{1,6}$, FERNANDO MACHADO DE MELLO ${ }^{1,5}$, JOSÉ MARQUES CORREIA-NEVES ${ }^{4}$, ANDRE ROGER GIRET ${ }^{3}$, JAQUES MOUTTE ${ }^{1}$, KAZUO FUZIKAWA ${ }^{4}$ AND MARIA LOURDES SOUZA FERNANDES. ${ }^{2}$}

\begin{abstract}
Neoproterozoic granitoid suites in southeastern Brazil are closely related to the different tectonic events. Petrography, geochemistry and structural features allow to separate these rocks into pre-, syn-, late and post-tectonic granitoids. The whole emplacement process lasted less than $100 \mathrm{Ma}$ : from $595 \mathrm{Ma}$ for the pre-tectonic granitoids, to $500 \mathrm{Ma}$ for the post-tectonic ones. During this interval a 45 Ma magmatic quiet period (from 582 to $537 \mathrm{Ma}$ ) can also be characterized. Detailed field observations and mapping, coupled with petrological and geochemical observations, indicate an important role of the Archaean and Paleoproterozoic crust in the genesis of these granitoids, showing even evidences of some mantle interactions.
\end{abstract}

Keywords: Mantiqueira Structural Province; Pre-tectonic Granitoids; Syn-tectonic Granitoids; Post-tectonic Granitoids; Geochemical signatures; Magmatic and Tectonic Relationship; Minas Gerais-Brazil.

INTRODUCTION The arc-type structure, which develops over more than $47,500 \mathrm{~km}^{2}$ in southeastern Brazil, between the $17^{\circ}$ and $21^{\circ}$ $\mathrm{S}$ latitudes, is responsible of the sea-shore protuberance in northern Rio de Janeiro state, and links many lithospheric tectonic discontinuities to an abundant and various types of magmatism. A regional geologic synthesis of geotectonic and magmatic processes has been done for the southern part of the continental arc (Wernick 1990, Wiedemann 1993, Campos-Neto and Figueiredo 1995, Ebert et al. 1996). Although some work has been already performed (PedrosaSoares et al. 1999), in the northern part a critical review is still lacking.

So, this paper deals with a geochemistry and tectono-magmatic approach of southeastern Brazil emphasizing the northern part of the continental arc. The plutons intruded in Archaean and Paleoproterozoic magmatic and metamorphic basement were emplaced during different periods in relation to the geotectonic events.

GEOLOGICAL SETTING The mid-northern part of Mantiqueira Structural Province (Fig. 1), is located in the southeastern Brazil, eas of the São Francisco Craton (Pinto et al. 1997, Netto et al. 1998). This geological province is related to the Brasiliano orogeny (from 600 to $450 \mathrm{Ma}$ ), and it consists mainly of Neoproterozoic mobile belts surrounding the São Francisco cratonic block.

These structural units in the Mantiqueira Province are formed by: (i) early Proterozoic basement such as the high and low-grade metamorphic rocks which form the Piedade, Paraíba do Sul and Pocrane complexes; (ii) late-Proterozoic supracrustal sequences of the Rio Doce Group, and (iii) granitoids and pegmatites intrusions related to the mobile belt dynamics (Nalini 1997, Bilal et al. 1998). Deposits of rare metals, and gem-rich pegmatites are common along foliation planes of the Rio Doce Group metasedimentary rocks.

The regional geodynamic evolution has been sealed by the Governador-North Guaçui and the Vitoria shear zones. Two main folding phases (D1 and D2) were developed under amphibolite facies conditions before and after the granitic intrusions, respectively (Bilal et al. 1998, Nalini 1997).

The first deformation (D1) is responsible for the N10-30 penetrative foliation (solid state deformation) with western intermediate to vertical strips, and mineral lineation affecting both the host rocks and the pre- and syn-tectonic granitoids. The high density of these structural features suggests an important role of the shearing process during the emplacement of the granitoids.

The second deformation (D2) is outlined by cleavage crenulation, boudinage and normal faults, and it is related to an extensional phase following the intrusion of late and post-tectonic granitoids. Recent U$\mathrm{Pb}$ (Söllner et al. 1991; Machado et al., 1996) and Sm-Nd age determinations in the working region, are indicating two tectonometamorphic events, dated at 590-565 and 535-520 Ma respectively.

\section{GRANITOIDS OF SOUTHEASTERN BRAZIL Pre- tectonic granitoids The Galiléia granitoid, dated with $\mathrm{U}-\mathrm{Pb}$ age}
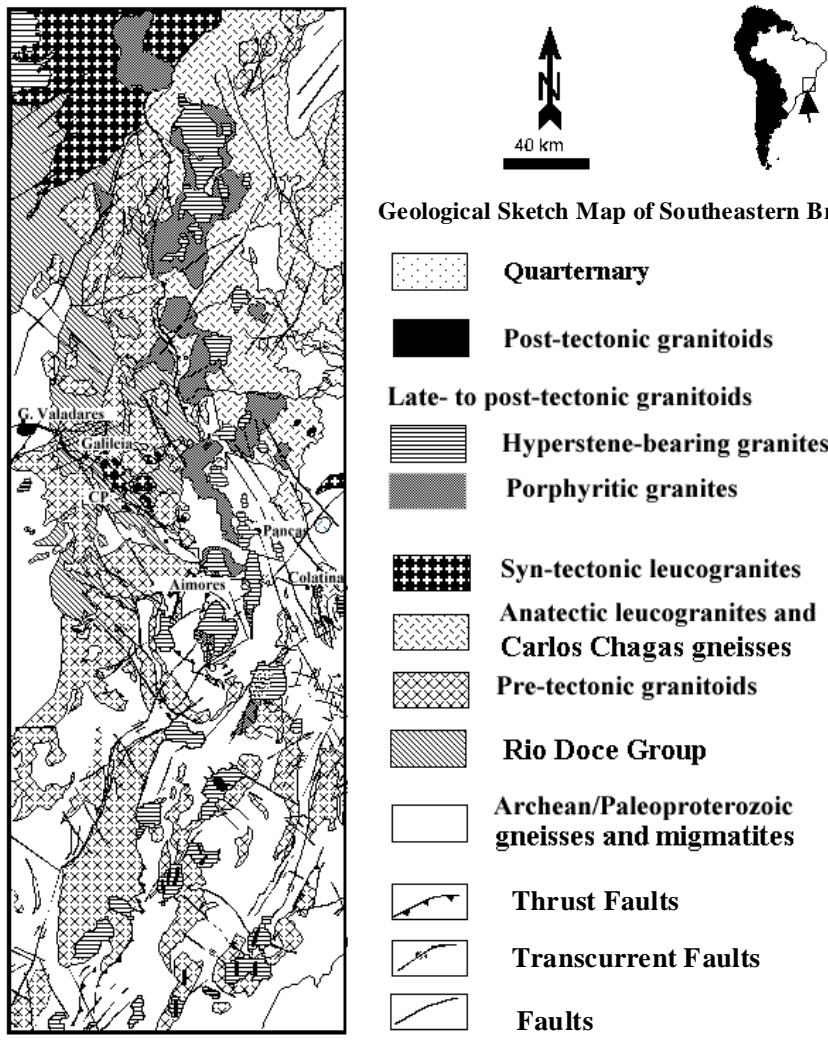

Geological Sketch Map of Southeastern Brazil

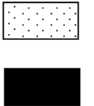

Quarternary

Post-tectonic granitoids

Late- to post-tectonic granitoids

琧高 Hyperstene-bearing granites

Porphyritic granites

Syn-tectonic leucogranites

Anatectic leucogranites and Carlos Chagas gneisses

浆䒵获 Pre-tectonic granitoids

Rio Doce Group

Archean/Paleoproterozoic gneisses and migmatites

Thrust Faults

Transcurrent Faults

Faults

Figure 1-Geological sketch map of southeastern Brazil. (CP-Conselheiro Pena; apud Pinto et al. 1997, modified according to our own observations.

of $595 \mathrm{Ma}$ (Nalini, 1997), is composed of several diapiric intrusions (Fig. 1) predominantly consisting of granodiorite and associated tonalites, granites, and microgranites with microgranular enclaves (Bilal et al. 1998, Nalini 1997). The enclaves show similar mineralogical phases, with the predominance of mafic ones. Grossularrich garnet $\left(\mathrm{Al}_{40-64} \mathrm{Gr}_{20-42} \mathrm{Sp}_{7-15} \mathrm{Py}_{3-9}\right)$ and Ca-rich plagioclase $\left(\mathrm{An}_{70-80}\right)$ in the granitoids are considered to be xenocrysts extracted from the magmatic enclaves.

Syn-tectonic granitoids They are represented by the Urucum granitoids with U-Pb age of 582 Ma (Nalini 1997) intruding the Galiléia suite and the São Tomé schists, both occurring as xenoliths in the granitoids. The syn-tectonic emplacement of these suites is attested by a magmatic foliation, parallel to the regional foliation $\left(\mathrm{N} 10-30^{\circ} \mathrm{W} /\right.$

1 Ecole des Mines de Saint-Etienne (France) ebilal@admunix.emse.fr;

2 Instituto de Geociências, Universidade Federal de Minas Gerais (Brazil);

Université Jean Monnet (France);

CNEN-CDTN (Belo Horizonte-Brazil)nevesj@urano.cdtn.br;

DGEO-UFRRJ (Brazil);

DGEO-UFOP (Brazil) 
$\mathrm{N} 55-75^{\circ} \mathrm{W}$ ) of country rocks. In the Urucum granitoids, the presence of solid state foliation and mylonitic textures along the margins, and magmatic foliation in the center of the bodies (Nalini 1997) suggest that subvertical shearing movements were important during the magma emplacement. Five types of granitoids have been distinguished in the Urucum suites, namely: porphyroid granite, fine- to medium-grained granite, tourmaline-rich granite, aplopegmatite and gem-rich pegmatite.

Late to post-tectonic granitoids Ring-like intrusive complexes (from 537 to $520 \mathrm{Ma} \mathrm{U} / \mathrm{Pb}$ ) are located in the Espírito Santo and Minas Gerais states. These plutons intrude the Juiz de Fora and the Paraíba do Sul Complexes of Archaean to Proterozoic ages. They consist of six main intrusions and several smaller ones. Their structures were described by Horn et al. (1996, 1998).

Three mains types of rocks have been recognized in different ringlike intrusions. They present a structure with fine-grained diorite at the center and hypersthene-bearing granite and/or granodiorite at the margins or at the roof of intrusion. The intraplutonic contacts are gradational showing intense mixing and mingling processes. All the previous facies of the ring-like intrusive bodies are penetrated by a porphyritic granitoid suite mainly made by coarse-grained granite, granodiorite, fine-grained granite, and vein-dykes of simple pegmatites. Their relative volume does not exceed $10 \%$ of the ring massifs.

Post-tectonic granitoids The Ibituruna syenite complex, and the Aracé and the Garrafão complexes (Vieira 1993) consists mainly of syeno-granite and syenite, and in lesser amounts, granite and gabbro. The most important of them is the Ibituruna syenite complex (511 Ma $\mathrm{Rb}-\mathrm{Sr}, 509 \pm 4 \mathrm{Ma} \mathrm{U}-\mathrm{Pb}$ age), which intrudes the early-Proterozoic basement. This complex presents predominant fine-grained syenite and quartz syenite (Bilal and Correia-Neves 1997), which are cut by many dykes of alkaline granite, of which the largest one was emplaced as a ring dyke in the south-western border of this complex. The syenites always contain dark enclaves and mafic and ultramafic xenocrysts of early magmatic crystallization.

These post-tectonic granitoids are known to the south of Governador Valadares in small scattered bodies whose representation on the sketch geological map (Fig. 1) is not possible at scale.

GEOCHEMICAL FEATURES The evolution of granitoids series in the Brazilian southeastern region is well characterized by zirconium evolution, whose discriminating role is emphasized in the $\mathrm{Zr}$-ASIFMMT triangle diagram, where ASI = Aluminum Saturation Index, and $\mathrm{FMMT}=\mathrm{FeO}+\mathrm{MgO}+\mathrm{MnO}+\mathrm{TiO}_{2}$ (Fig. 2) . This diagram, which shows the common FMMT trend of fractionation, outlines two main $\mathrm{Zr}$-ASI trends. The first trend encompasses the pre-tectonic series (metaluminous) and corresponds to an ASI increase, which is enhanced in the syn-tectonic series (peraluminous) due to early crystallization of zircon, which causes strong $\mathrm{Zr}$ depletion. The porphyritic facies of the late-tectonic series evolve similarly to this trend. The second trend corresponds to a $\mathrm{Zr}$ enrichment, which affects the late and post-tectonic granitoids.

The duality between the pre- and syn-tectonic granitoids in one hand, and the late and post-tectonic ones in the other, is also shown by spidergrams (Fig. 3) grouping the trace elements and the Rare Earth Elements (REE) normalized with the Pearce et al. (1984) values.

The pre- and syn-tectonic granitoids are characterized by a significant Ba depletion, whereas the enrichment of this element is observed in the late and post-tectonic granitoids. These last granitoids display spidergrams which may be compared to those of the Vedrette di Ries alpine belt, a precursor of the alpine mountains, to the Sabaloka complex, in Sudan, to the Gabug granites in the Tibetan Himalayan belt, and to the Yunnan granitoids, SW China, all of them being related to continent-continent collisions. The positive $\mathrm{Th}, \mathrm{Ce}$ and $\mathrm{Sm}$ anomalies of the post-tectonic granitoids may be related to a high crustal contamination of the magmas, which is outlined by the $\mathrm{Rb}, \mathrm{Th}$, $\mathrm{Ce}$ and $\mathrm{Sm}$ high contents in the other series. The role of the crust is also confirmed by the isotopic data.

MAGMATISM AND TECTONIC RELATIONSHIPS The two main tectonic episodes are represented by a deformation (D1), which corresponds to a collisional event, and by a deformation (D2),

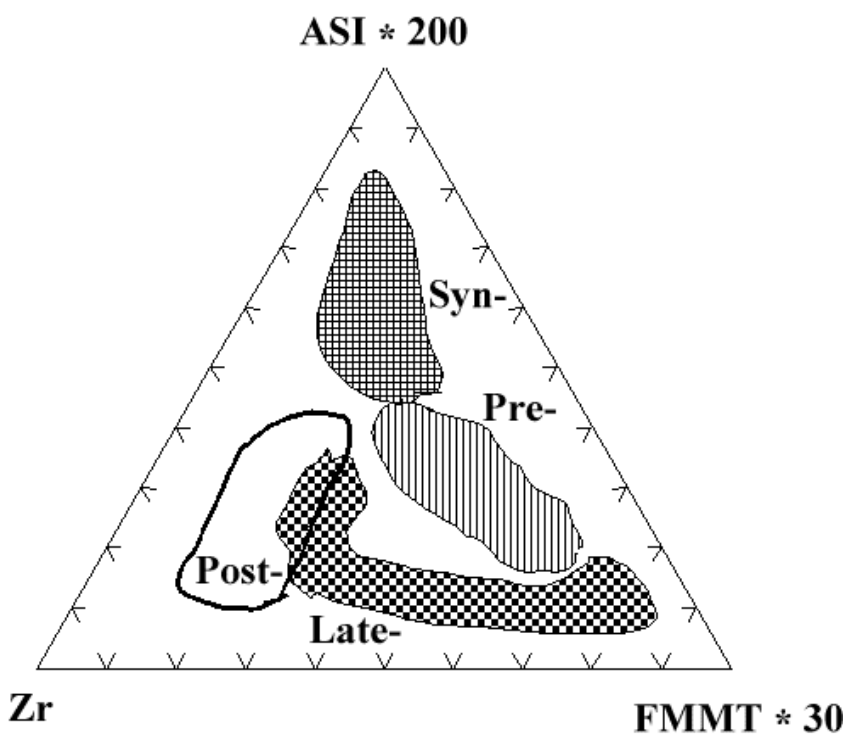

Figure 2-Neoproterozoic granitoids of southeastern Brazil plotted in the $\mathrm{Zr}$ ASI*200-FMMT*30 diagram. The Brazilian pre-tectonic, syn-tectonic, latetectonic, and post-tectonic granitoids fall in well-defined fields.

characteristic of an extensional episode, both being respectively related to the first (pre-and syn-tectonic granitoids) and to the second (late and post-tectonic granitoids) main magmatic stages.

The pre-tectonic granitoids, i.e. those of the Galileia suites, have an age of $595 \mathrm{Ma}$ and they were emplaced (Fig. 4) under high pressure (8 to $10 \mathrm{kbar}$ ) and high temperature $\left(750\right.$ up to $\left.850^{\circ} \mathrm{C}\right)$. Some features of them, such as the Ca-rich plagioclase, the grossular-rich garnet and the mafic enclaves may be related to a mantle origin. Other features, such as the two zircon populations, and the very Sr-enriched, and Nddepleted initial ratios: both $\left(0.712\left[{ }^{87} \mathrm{Sr}^{86} \mathrm{Sr}_{(\mathrm{i})}[0.713)\right.\right.$ and ($8.9\left[\varepsilon^{2}{ }_{(600)}[-9.3)\right.$, point to an important role of a crustal source (Nalini et al. 1998b). These pre-tectonic granitoids must, therefore, be considered as hybrid rocks since they reflect the mingling and/or mixing of crustal and mantle derived magmas. Evidence of late reequilibration processes under a pressure of $4 \mathrm{kbar}$ and a temperature of $700^{\circ} \mathrm{C}$, corresponding to the collisional deformation D1, implies in an exhumation dynamic involving decompression and thermal relaxation, both leading to the partial melting of the surrounding Paleoproterozoic metasediments, and consequently, to the simultaneous production of leucogranites (Urucum suites) and the first pegmatite group, both belonging to the syn-tectonic granitoids of $582 \mathrm{Ma}$ age.

Considering the time-span exhumation, i.e. the ages of the pretectonic (595 Ma) and of the syn-tectonic granitoids (582 Ma), and the respective thermobarometric data (8-10 to $4-5 \mathrm{kbar}$ ), the exhumation process occurred quite rapidly, in the range of $2 \mathrm{~mm}^{-1} \mathrm{y}^{-1}$, which may explain the preservation of the composition of early minerals, such as plagioclases and garnet. These results are in agreement with chronological tectono-metamorphic studies (Söllner et al. 1991, Machado et al. 1996) giving ages from 590 to $565 \mathrm{Ma}$ for the D1 events at a regional scale.

The second main tectono-magmatic period is well delimited in time from 537 to $520 \mathrm{Ma}, 45 \mathrm{Ma}$ later than the previous event. As expressed by the thermobarometric diagram (Fig. 4), the second period of deformation (D2), which corresponds to an extensive episode, is also related to a thermal event. During that period, the major crustal thrusts have been rejuvenated, leading to a quick exhumation of the adjacent high-grade gneissic rocks, such as the complexes of Juiz de Fora and of Paraíba do Sul. The uplifting rate is similar to that of the metamorphic zones in a collisional orogeny, following isostatic adjustments. The so-called late-tectonic granitoid ring-like complexes were emplaced during that extensive episode. The intrusions are related to lateral opening of blocks formed by the superposition of thrusting and strike-slip faulting tectonics. During the D2 events, a second partial melting of the crust occurred and produced simultaneously the porphyritic leucogranites and the second generation of less evolved and differentiated pegmatites. Petrological and 


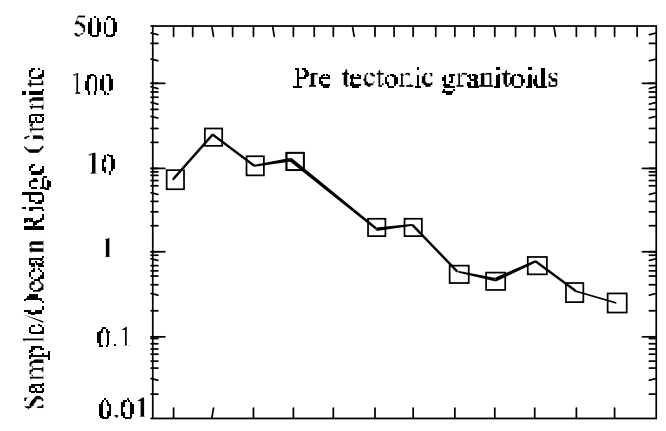

$\mathrm{K}_{2} O$ Rb Bath $\mathrm{Nb}$ Ce Hf Zr Sm Y Yb

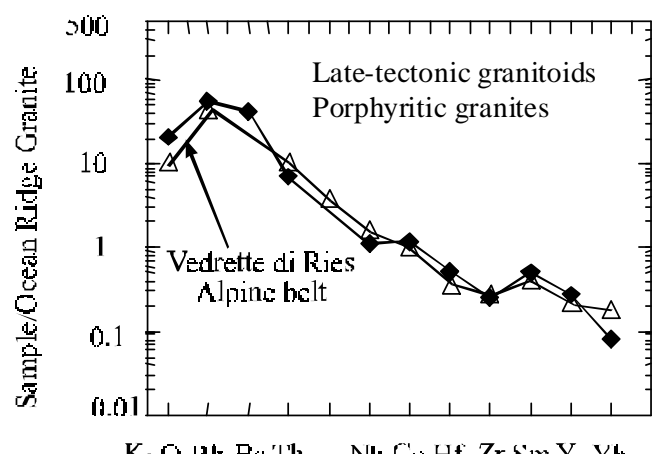

$\mathrm{K}_{2} \mathrm{O}$ Rl? Bath $\mathrm{Nb}$ Ce Hf 7r Sim Y Yb

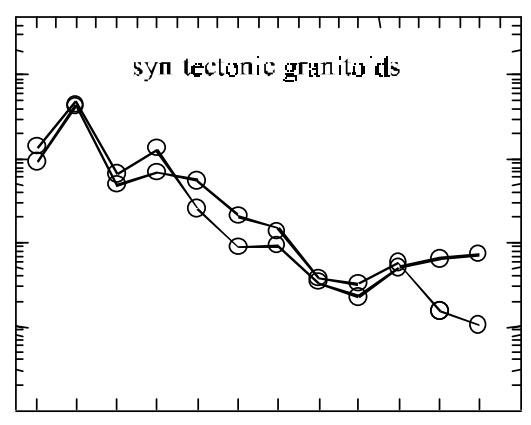

$\mathrm{K}_{2} \mathrm{O}$ Rh DaTh NhCe Hr ZrSm Y Yh

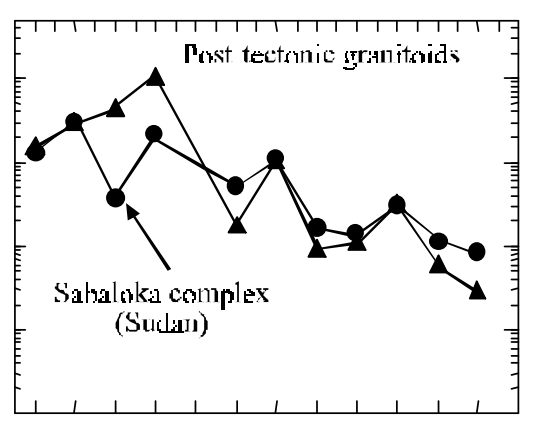

$\mathrm{K}_{2}$ () Rb BaTh NbCeIIf $Z \mathbf{r S m} Y \mathrm{Yb}$

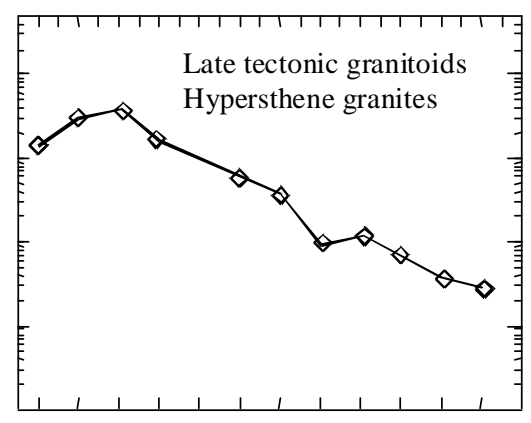

$\mathrm{K}_{2} \mathrm{ORb} \mathrm{DaTh} \quad \mathrm{Nb} \mathrm{Ce} \mathrm{Hf} \mathrm{ZrSmY} \mathrm{Yb}$

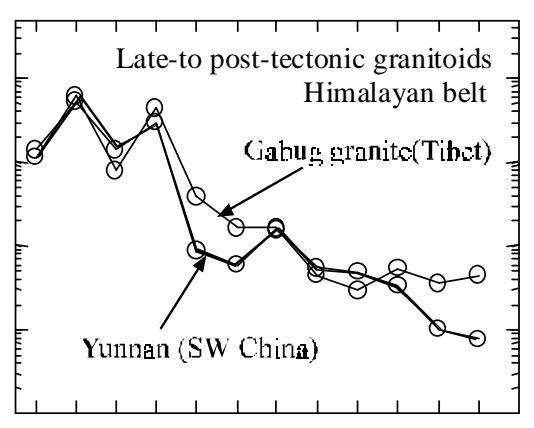

$\mathrm{K}_{2} \mathrm{O}$ Rb BaTh $\mathrm{NbCe}$ Iff $Z \mathbf{r} \mathrm{Sm} Y \mathrm{Yb}$

Figure 3-Brazilian southeastern granitoid spidergrams, as compared with those of well-characterized crustal granites.

Temperature ${ }^{\circ} \mathrm{C}$

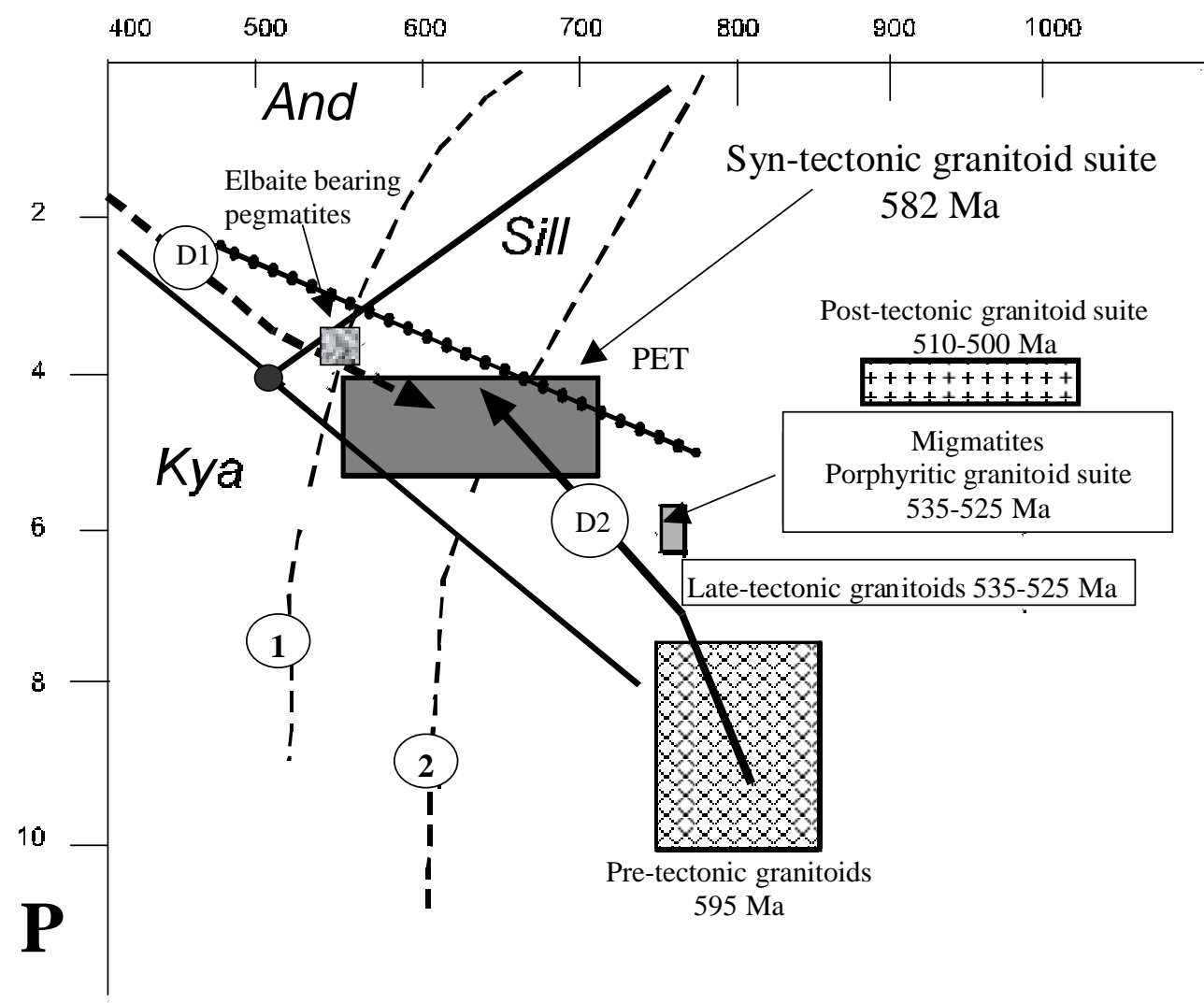

Figure 4-P-T-t diagram concerning Neoproterozoic granitoids in southeastern Brazil. [0- Triple point; Kya- kyanite; And-andalusite and Sill- sillimanite; 1)Harding Pegmatite solidus; (2)-Granite solidus; D1 and D2-P-T-t Deformation paths; PET-petalite; SPD-spodumene. P-Pressure in K bar; L-boundary between Petalite and Spodumene]. 
geochemical signatures of the porphyritic granitoids attest of a crustal origin different from that of the syn-orogenic suites, and the source material is probably the high grade metamorphic rocks, i.e. the orthogneiss.

This last extensive period, closed by the emplacement of the posttectonic granitoids, is well recorded in the Ibituruna, the Aracé and the Garrafão massifs. In these syenitic and granitic plutonic bodies, the presence of numerous ultramafic enclaves brings out the role of a mantle source. Structurally, such framework may be explained by a lithospheric scale of the post-Brasiliano strike-slip faults allowing the uplift of mantle melts into the upper crust.
Acknowledgements This paper is the result of a team-work research program concerning granitoids from Minas Gerais (Brazil) and supported since 1992 by the following Brazilian and French Institutions: CNPq, CAPES, FAPEMIG, CNEN/CDTN, Federal University of Minas Gerais (UFMG), Federal University of Ouro Preto (UFOP), Ecole des Mines de Saint-Etienne, Université Jean Monnet, Saint-Etienne, CNRS, and COFECUB. The manuscript has been improved greatly from the critical comments of two anonymous reviewers. We are also grateful to Dr. Francisco Javier Rios for his assistance during computer drafting of figures. We are indebted to all these supporters.

\section{References}

Bilal E. \& Correia Neves J.M. 1997. Neoproterozoic Ibituruna syenite complex (Minas Gerais state, Brazil). In: International Symposium on Granites and Associated Mineralizations, ISGAM, 2, Salvador, Excursions guides book:119-120.

Bilal E., Nalini H.A., Horn, A.H., Correia-Neves, J.M., Giret, A.R., Fuzikawa, K. Fernandes, M.L.S., Mello, F., Moutte, J. 1998. Neoproterozoic granitoid suites of Rio Doce Region, Brazil. In: International Conference on Precambrian and Craton Tectonics, Ouro Preto. Extended Abstracts: 41-43

Campos-Neto M.C. \& Figueiredo, M.C.H. 1995. The Rio Doce orogeny, southeastern Brazil. Journal of South American Earth Sciences, 8(2):143-162.

Ebert H.D., Chemale F., Babinski M., Artur A.C, Van Schmus W.R. 1996. Tectonic setting and $\mathrm{U} / \mathrm{Pb}$ zircon dating of the plutonic Socorro Complex in the Transpressive Rio Paraiba do Sul Shear Belt, SE Brazil. Tectonics, 15(2):688-699.

Horn A.H., Giret A.R., Bilal E., Correia-Neves J.M., Carvalho S. 1996. O complexo intrusivo Ibituba-Itapina, noroeste do estado de Espírito Santo- resultados e caracterização preliminares. In: SBG, Congresso Brasileiro de Geologia, 39, Salvador, Anais, 6:375-378.

Horn A.H., Giret A.R., Bilal E., Correia-Neves J.M.1998. Der Ibituba-Itapina Intrusiv Komplex im Ribeira Mobile Belt, Espírito Santo, Brasilien. Lateinamerika Kolloquium, Bayreuth, Germany. Zusammensfassungen Heft:56-57.

Machado N., Valladares C., Heilbron M., Valeriano C. 1996. U-Pb geochronology of the central Ribeira belt (Brazil) and implications for the evolution of the Brazilian Orogeny. Precambrian Research, 79:347-361.

Nalini H.A. 1997. Caractérisation de suites magmatiques néoprotérozö̈ques de la région de Conselheiro Pena et Galiléia (Minas Gerais, Brésil). Ecole des Mines de SaintEtienne, France, Ph.D. thesis. 321 p.

Netto C., Araujo M.C., Pinto C.P., Drumond J.B.V. 1998. Cadastramento de Recursos Minerais da Região leste de Minas Gerais, Pegmatitos. MME/CPRM - SEME/ COMIG, Belo Horizonte,. 200 p.
Pearce J.A., Harris N.B., Tindle A.G. 1984. Trace element discrimination diagrams for the tectonic interpretation of granitic rocks. Journal of Petrology, 25(4):956-983.

Pedrosa-Soares A.C., Wiedemann C.M., Fernandes M.L.S., Faria L.F., Ferreira J.C.H. 1999 Geotectonic significance of the Neoproterozoic granitic magmatism in the Araçuai Belt: A model and pertinent questions Rev. Bras. Geoc. 29(1):59-66.

Pinto C.P., Drumond J.B.V., Feboli W.L.(Orgs.) 1997. Projeto Leste: Geologia-Nota Explicativa do Mapa Geológico Integrado, Etapa I, Folhas SE-24V, SE-23Z, SE$24 Y$ (partes). Escala 1:500.000. Etapa I. Belo Horizonte. MME/CPRM - SEME/ COMIG. $205 \mathrm{p}$

Söllner F., Lammerer B., Weber-Diefenbach K. 1991. Die Krustenentwicklung in de Küstenregion nördlich von Rio de Janeiro/Brasilien. Münchener Geologishe Hefte, 4, $100 \mathrm{pp}$.

Vieira V.S. 1993. Texto Explicativo da folha SE. 24-Y-C-V, Baixo Guandu. Programa levantamentos Geologicos Basicos do Brasil. DNPM/CPRM, Brasilia, 113p.

Wernick E. 1990. Zoneamento magmático regional de granitoides brasilianos no sudeste/sul do Brasil : implicações geotectônicas. In: SBG, Congresso Brasileiro de Geologia, 36. Natal, Anais 4:1668-1683.

Wiedemann C.M. 1993. The evolution of the early Paleozoic, Late- to post-collisional magmatic arc of the Coastal Mobile Belt, in the state of Espírito Santos, eastern Brazil. Anais da Academia Brasileira de Ciências. 65:163-181.

Contribution IGC-082

Received February 25, 2000 Accepted for publication May 2, 2000 